\title{
Nye spilleregler må til for å stoppe ebolaepidemien
}

\author{
Vi står overfor en ebolaepidemi som kan få et enormt omfang om det ikke iverksettes mer effektive mottiltak. \\ Det finnes vaksiner og antivirale midler, men ingen av dem er etter vanlige regler klare til bruk på mennes- \\ ker. Verdens helseorganisasjon har nå godkjent at eksperimentell behandling kan tas i bruk. Det er klokt, \\ men fortsatt kanskje for forsiktig, og for sent.
}

Undertegnede var nylig i Monrovia, Liberia, på oppdrag for Leger Uten Grenser (MSF) og fikk i løpet av oppholdet se med egne øyne hvordan denne sykdommen kan utslette friske familier på få dager. Den pågående ebolaepidemien er den mest alvorlige hittil. Det er for tidlig å si hvordan den vil utvikle seg, siden man ikke har oversikt over hvor utbredt eller hvor smittsomt viruset er. Varigheten og omfanget av den pågående epidemien tyder på at dette viruset ikke blir svekket gjennom smittekjeden. Dets epidemiologiske reproduksjonsrate $\left(\mathrm{R}_{0}\right)$ er i dette utbruddet beregnet å være 1,6-2,0, med generasjonstid 15 dager (1), men dette er basert på målinger som er gjort mens det fortsatt var fungerende kontrolltiltak.

Hjelpeapparatets kapasitet tillater nå at bare en liten del av de smittede blir tatt hånd om. Det er sannsynlig at lokalsamfunnene selv vil sette $\mathrm{i}$ verk mottiltak for å bremse smitten. Jeg så en gruppe fra et lokalsamfunn som var blitt malt hvite i ansiktet for å markere at de var mistenkte ebolapasienter. Om krisen forverres ytterligere, er det all grunn til å frykte at mer drastiske tiltak kan forekomme. Om verdenssamfunnet ikke raskt nok klarer å mobilisere de nødvendige ressursene, kan i verste fall de fattigste landene få en epidemi av umåtelig størrelse, ledsaget av en humanitær katastrofe som følge av desintegrering av samfunnsstrukturer, lovløse tilstander og stans i produksjon, import og fordeling av mat.

\section{Lovende vaksiner}

Ebolaviruset deles inn i flere subtyper, og den aktuelle i Vest-Afrika er Zaire-ebolavirus. Ubehandlet er dødeligheten av denne subtypen $80-90 \%$, men overlevelsen kan bedres noe med understøttende behandling (2). I tillegg til å forsøke å bekjempe epidemien med smittesporing og isolering ville det vært ønskelig å kunne vaksinere og gi antiviral behandling. I en ekspertpaneldiskusjon arrangert av Verdens helseorganisasjon (WHO) 11. august 2014 konkluderte man med at det $\mathrm{i}$ denne situasjonen kan forsvares å iverksette eksperimentell behandling på mennesker med medikamenter som ikke har vitenskapelig dokumentert effekt og ikke er fullt karakterisert med tanke på sikkerhet og bivirkninger hos mennesker. Ekspertpanelet forutsatte at en slik bruk følger etiske regler, med informert sam- tykke, at fordelingen av slik behandling gjøres rettferdig og at alle data rundt behandlingen samles systematisk slik at man kan lære av dem (3). De nevnte ikke eksplisitt at det bør gjøres i form av placebokontrollerte kliniske forsøk, selv om det er den beste måten å unngå feilslutninger på, slik det konkluderes i en etterfølgende kommentar i The Lancet (4).

En vaksine utviklet av GlaxoSmithKline (GSK) og National Institute of Allergy and Infectious Diseases (NIAID) er nå klar til fase 1-utprøvning i Storbritannia, Gambia og Mali så snart behandling av etisk godkjenning foreligger. Man håper at vaksinens sikkerhet vil være avklart før utgangen av

\section{«Tiden arbeider \\ mot oss i den aktuelle epidemien»}

dette året, slik at man deretter kan starte klinisk utprøvning på befolkningen i risikoområdene. Denne vaksinen er basert på en levende virusvektor, sjimpanseadenovirus type 3 (ChAd3), med genetisk materiale fra ebolavirus. Ifølge en pressemelding fra GSK viser undersøkelser på aper som ble smittet med ebolavirus at beskyttelsen er lovende (5).

En annen lovende ebolavaksineplattform, utviklet av bl. a. Public Health Agency of Canada, er basert på rekombinant vesikulær stomatitt-virus (rVSV) (6). En utprøvning av forskjellige rVSV-vaksiner ga $100 \%$ beskyttelse mot ebolavirus preeksposisjonelt hos aper, men ingen kryssimmunitet mellom Zaire-ebolavirus og Sudan-ebolavirus (7). Overraskende nok kunne vaksinene også brukes posteksposisjonelt. I forsøk med Marburg-virus, et virus i samme taksonomiske familie som ebolaviruset, overlevde fem av seks aper når vaksinen ble gitt 24 timer etter, og to av seks når vaksinen ble gitt 48 timer etter en dødelig virusdose (8).

Også Bavaria Nordic arbeider med en ebolavaksine og planlegger å starte fase 1studier i 2015 (9). Det vil være et stort skritt fremover om helsearbeidere, hygienestab og smittekontakter kan vaksineres mot ebolavirus. Tiden arbeider mot oss i den aktuelle epidemien. Ultrarask etisk godkjenning av utprøvning fra WHO og nasjonale helsemyndigheter vil være avgjørende.

\section{Medikamentell behandling}

Det er ingen registrerte antivirale medikamenter med dokumentert effekt mot ebolavirus hos mennesker. En publikasjon fra 1999 viste effekt av en rekke nukleosidanaloger (S-adenosylhomocystein hydrolase-inhibitorer) på ebolavirus i cellekulturer. En av dem, Ca-c3Ado, ble testet i mus. Med den ebolavirusdosen som ble gitt, døde alle de ubehandlede musene etter 5-7 dager. Av dem som fikk over $0,7 \mathrm{mg} / \mathrm{kg}$ Ca-C3Ado fra dag $0-1$, overlevde alle. Ved behandlingsstart dag 2-3 overlevde henholdsvis $90 \%$ og $40 \%$ (10). At disse funnene ikke er blitt fulgt opp, illustrerer at ebolavirus inntil nå har vært et lite prioritert felt.

Nukleosidanalogen BCX4430, som virker på både ebolavirus og Marburgvirus, ble gitt til aper én time, 24 timer og 48 timer etter at de ble påført Marburgvirusinfeksjon. 17 av 18 aper i behandlingsgruppen overlevde, mens alle seks i kontrollgruppen døde. Det vurderes nå å starte fase 1-utprøvning av BCX4430 $(11,12)$. Enda ett middel, TKM-Ebola, basert på siRNA, er under fase 1-utprøvning (13). Et annet behandlingsprinsipp kan være glukosidaseinhibitorer, som hemmer virusets morfogenese (14).

Spesifikke monoklonale antistoffer har i to studier hatt effekt på aper som har startet med medisinen henholdsvis én time og 24 timer etter at de ble smittet med ebolavirus $(15,16)$. Dette preparatet er blitt gitt til ebolasyke mennesker under navnet ZMapp, som en såkalt medlidenhetsbehandling. Så vidt jeg har kunnet se i medier er det foreløpig bare sju mennesker med ebolavirusinfeksjon som har fått ZMapp. Fem har overlevd, hvorav i hvert fall to allerede var i bedring da de fikk det. Så langt er det ikke mulig å si om det har noen effekt. Det er nå tomt for preparatet, og det vil ta lang tid å lage mer. Et middel som det er så komplisert å produsere vil nødvendigvis bli svært dyrt, og det er vanskelig å tro at det noensinne vil kunne ha en plass ved store utbrudd i ressursfattige land.

I et ekspertpanelmøte 5. september 2014 gikk WHO inn for å forsøke å gi smittede 
pasienter transfusjon av blod fra mennesker som har overlevd ebolavirusinfeksjon (17). Den eneste vitenskapelige publikasjonen om dette er en rapport fra Den demokratiske republikken Kongo, der sju av åtte ebolapasienter som fikk rekonvalesentblod overlevde (18). Behandling med blodtransfusjoner vil i en katastrofesituasjon der man knapt nok har kapasitet til å ta hånd om de døde, by på betydelige logistiske problemer. På sikt kan det kanskje utvikles et anti-ebolavirus-immunglobulin.

\section{Nye spilleregler}

En potensielt fruktbar tilnærming er å lete etter effekt mot ebolavirus hos allerede registrerte og gjennomprøvde medikamenter der bivirkninger og sikkerhet hos mennesker allerede er vel karakterisert. Madrid og medarbeidere fant en anti-ebolaviruseffekt av klorokin, der ni av ti mus i behandlingsgruppen overlevde (19). Musene fikk en mye høyere dose klorokin enn hva vi bruker $i$ behandling av malaria. En annen studie testet østrogenreseptorinhibitorer in vitro og i en musemodell (20). De fant at $90 \%$ av musene overlevde om de fikk klomifen injisert én time etter injeksjon av en dødelig dose ebolavirus. Klomifen brukes vanligvis til å behandle anovulasjon. Stoffet har vært så lenge på markedet at det finnes generiske preparater, og det er derfor billig og lett tilgjengelig.

Et nytt japansk antiviralt middel, T-705 (favipiravir), er under fase 3-utprøvning til bruk mot influensa. Da dette medikamentet ble utprøvd på mus, overlevde alle som fikk behandling dag 6 etter at de ble smittet med ebolavirus (det var etter at det hadde begynt å komme tegn på sykdom), mens alle musene i kontrollgruppen døde. De musene som fikk behandling fra dag 8 hadde ikke signifikant bedre overlevelse enn kontrollgruppen (21). Jeg mener det nå bør være en høy prioritet for verdenssamfunnet å teste flere allerede tilgjengelige medikamenter for mulig virkning mot ebolavirus. Da kan man så raskt som mulig komme i gang med utprøvning av kombinasjonsterapier for å unngå resistensutvikling.

Ideelt sett bør effekten av medikamentene testes ut på aper med ebolavirusinfek- sjon før det iverksettes en klinisk utprøvning på mennesker. Ved antivirale midler er det viruset, og ikke vertsorganismen, som er medikamentets angrepspunkt. Forsøk på mus vil derfor være mer relevant i forhold til bruk på mennesker enn om man for eksempel tester ut blodtrykksmedisin. De viktigste forskjellene vil gjelde farmakokinetikk, bivirkningsprofil og toksisitet. Forsøk med aper er ressurskrevende, ikke ufarlig og tar tid å forberede. Det må også kunne stilles spørsmål ved om det i denne situasjonen er mer etisk å infisere aper med ebolavirus enn å gi noen ebolasyke mennesker en sjanse. Situasjonen rundt ebolaepidemien er så prekær, og tidsfaktoren så avgjørende, at jeg mener det kan forsvares å endre spillereglene i det godes tjeneste. Det virker som en klok avgjørelse av WHO å nå åpne for bruk av eksperimentell ebolabehandling direkte på mennesker.

\section{Gunnar Hasle}

hasle@reiseklinikken.com

Gunnar Hasle (f. 1954) er spesialist i infeksjonssykdommer og driver Reiseklinikken i Oslo. Hans ph.d.-avhandling var i skjæringspunktet mellom zoologi og medisin.

Forfatter har fylt ut ICMJE-skjemaet og oppgir ingen interessekonflikter.

\section{Litteratur}

1. Fisman D, Khoo E, Tuite A. Early epidemic dynamics of the West African 2014 Ebola outbreak: Estimates derived with a simple two-parameter model. PLoS Curr 2014; e-publisert 8.9.2014.

2. Peters CJ. Marburg and Ebola virus hemorrhagic fevers. I: Mandell, Douglas and Bennets's. Principles and practise of infectious diseases. Churchill Livingstone 2000; 1821-1823.

3. WHO. Ethical considerations for use of unregistered interventions for Ebola virus diseaes (EVD). www.who.int/mediacentre/news/statements/2014/ ebola-ethical-review-summary/en/ (16.9.2014).

4. Rid A, Emanuel EJ. Ethical considerations of experimental interventions in the Ebola outbreak. Lancet 2014; e-publisert 22.8.2014.

5. GSK press releases. www.gsk.com/en-gb/media/ press-releases/2014/ebola-vaccine-trials-fasttracked-by-international-consortium/ (16.9.2014).

6. Geisbert TW, Feldmann H. Recombinant vesicular stomatitis virus-based vaccines against Ebola and Marburg virus infections. J Infect Dis 2011; 204 (suppl 3): S1075-81.
7. Jones SM, Feldmann H, Ströher $U$ et al. Live attenuated recombinant vaccine protects nonhuman primates against Ebola and Marburg viruses. Nat Med 2005; 11: 786-90.

8. Geisbert TW, Hensley LE, Geisbert JB et al. Postexposure treatment of Marburg virus infection. Emerg Infect Dis 2010; 16: 1119-22.

9. Bavarian-Nordic. Bavarian Nordic accelerates Ebola vaccine development programs in collaboration with the U.S. National Institutes of Health. www.bavarian-nordic.com/investor/ news.aspx?news $=4073(16.9 .2014)$.

10. Huggins J, Zhang Z-X, Bray M. Antiviral drug therapy of filovirus infections: S-adenosylhomocysteine hydrolase inhibitors inhibit Ebola virus in vitro and in a lethal mouse model. J Infect Dis 1999; 179 (suppl 1): S240-7.

11. Warren TK, Wells J, Panchal RG et al. Protection against filovirus diseases by a novel broad-spectrum nucleoside analogue BCX4430. Nature 2014 508: 402-5

12. Bray N. Spanner in the works of filovirus infection Nat Rev Drug Discov 2014; e-publisert 11.4.2014.

13. Tekmira. About investigational TKM-Ebola therapeutic. www.tekmira.com/pipeline/tkm-ebola.php (16.9.2014)

14. Chang J, Ju-Tao G, Du Y et al. Imino sugar glucosidase inhibitors as broadly active anti-filovirus agents. Emerg Microbes Infect 2013; 2: e77.

15. Olinger GG Jr, Pettitt J, Kim D et al. Delayed treatment of Ebola virus infection with plant-derived monoclonal antibodies provides protection in rhesus macaques. Proc Natl Acad Sci U S A 2012 109: $18030-5$

16. Qiu X, Audet J, Wong G et al. Successful treatment of ebola virus-infected cynomolgus macaques with monoclonal antibodies. Sci Transl Med 2012; 4: 38ra81

17. Butler D. Blood transfusion named as priority treatment for Ebola. Therapy uses serum from disease survivors, but data on effectiveness is scarce. Nature 2014; e-publisert 5.9.2014.

18. Mupapa K, Massamba M, Kibadi Ket al. Treatmen of Ebola hemorrhagic fever with blod transfusions from convalescent patients. J Infect Dis 1999; 179 (suppl 1): 18-23.

19. Madrid PB, Chopra S, Manger ID et al. A systema tic screen of FDA-approved drugs for inhibitors of biological threat agents. PLOS ONE 2013; 8: e60579.

20. Johansen LM, Brannan JM, Delos SE et al. FDAapproved selective estrogen receptor modulators inhibit Ebola virus infection. Sci Transl Med 2013; 5: 190ra79

21. Oesterreich L, Ludtke A, Wurr S et al. Successfull treatment of advanced Ebola virus infection with T-705 (favipinavir) in a small mammal model. Antiviral Res 2014; 105: 17-21

Mottatt 16.9. 2014 og godkjent 20.9. 2014. Redaktør: Hanne Støre Valeur.

Publisert først på nett. 